\title{
Therapeutic phytoelemental profile of Trichosanthes dioica
}

\author{
Prashant Kumar Rai ${ }^{1,2 \star}$, Surekha Shukla ${ }^{1}$, Shikha Mehta ${ }^{1}$, Nilesh Kumar Rai ${ }^{3,4}$, \\ A.K. Rai ${ }^{3}$, Geeta Watal ${ }^{1 *}$
}

${ }^{I}$ Alternative Therapeutics Unit, Drug Discovery \& Development Division, Medicinal Research Lab, Department of Chemistry, University of Allahabad, Allahabad 211002, India

${ }^{2}$ UJ Nanomaterials Science Research Group, Department of Chemical Technology, University of Johannesburg, P.O. Box 17011, Doornfontien 2028, Johannesburg, South Africa

${ }^{3}$ Laser spectroscopy research laboratory, Department of Physics, University of Allahabad, Allahabad 211002, India

${ }^{4}$ Department of Inorganic \& Physical Chemistry, Indian Institute of Science, Bangalore, India

*Corresponding author. Tel: (+91) 532 2462125; E-mail: geetawatal@gmail.com (G. Watal), and

pksherpuri@gmail.com (P.K. Rai)

Received: 17 July 2010, Revised: 20 Sept 2010 and Accepted: 21 Sept 2010

\section{ABSTRACT}

In India, Trichosanthes dioica is known as pointed gourd (in English), parwal (in Hindi) and potol (in Oriya) it is distributed in equatorial and subtropical regions and widely found in northern India. The present study is a unique example of interdisciplinary research as it deals not only with the phytochemical investigation of Trichosanthes dioica, using natural product technology but also correlates the presence of certain trace elements with its biological activities using Laser induced break down Spectroscopy (LIBS). The study reveals the isolation of one known and two unknown flavonoids and the presence of certain glycemic elements, responsible for the observed antidiabetic activity of Trichosanthes dioica. Hence, the presence of isolated flavonoids and trace elements can be very well correlated with its medicinal value. Copyright (C) 2010 VBRI press.

Keywords: Trichosanthes dioica; diabetes; LIBS; Indian herbs.

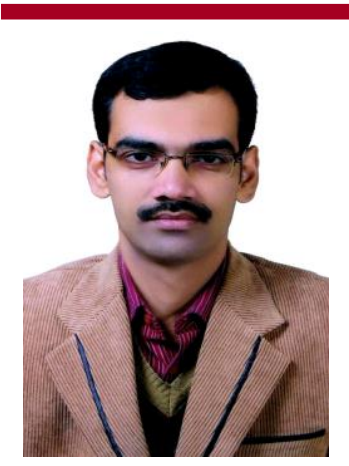

Prashant Kumar Rai is a core member of Dr. Watal's research group and has got his D. Phil. from the University of Allahabad, India in 2009. Dr. Rai has availed different fellowships viz. JRF, SRF and Research Associate of Indian Council of Medical Research, India and involved in developing phytotherapeutics for treating diabetes and complications associated with it. Dr. Rai's research interest is to explore traditional medicinal plants systematically and scientifically for their Bioactive potential. Dr. Rai's expertise lies in the area of antidiabetic, antioxidant, antilipedemic, and enzymatic studies in vivo and in vitro and at molecular and gene expression levels as well. Dr. Rai has one Patent and more than thirty International and National publications inclusive of two book chapters in "Methods in Molecular Biology Series", to his credit. Dr. Rai had been to Bethesda, MD, USA, in Nov.2008 and Basel, Switzerland, in Feb. 2010, for presenting his work at Annual meet of American Diabetes Technology Society and 3rd International ATTD Conference on Advanced Technologies \& Treatments for Diabetes, respectively. Dr. Rai has unfold the mystery involved in the role of elements playing, in causing and curing diabetes, using latest technology, LIBS and getting invitations from all over the world viz. Athens, Singapore, Malaysia, UK and South

Africa for presenting his work. At present he is working as a Post Doc Fellow, Department of Chemical Technology, University of Johannesburg, Johannesburg, South Africa.

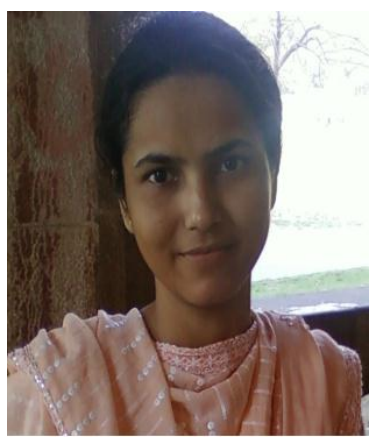

Surekha Shukla has done her graduation from G.N.D.U of Amritsar, India in 2005 and post graduation in Chemistry, from the University of Allahabad in 2008. Currently, Ms. Shukla has been enrolled for D. Phil. in 2009 in the Chemistry Department, University of Allahabad under the supervision of Dr. Geeta Watal and is a core member of Dr. Watal's research group. Ms. Shukla has a strong background of Natural Product technology and bioactivity testing, specially for antidiabetic and antioxidant activities in vivo as well as in vitro. She has an expert experimental hand in antimicrobial testing. Topic of her thesis is "Pharmacognostical Evaluation of Medicinally Important Plants and their compounds". Ms. Shukla has a number of good publications in journals of high repute and has presented her work in various National as well as International conferences. Her research interest is to develop more effective drugs of plant origin with low toxicity and at low cost. 


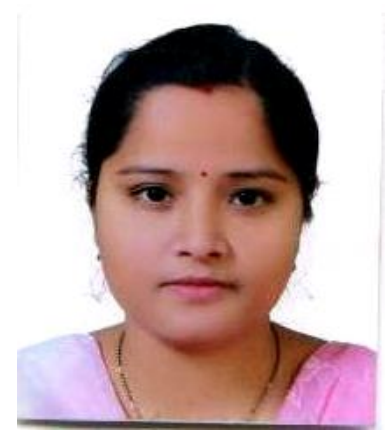

Shikha Mehta has a brilliant academic record having secured first division throughout her academic carrier and has completed her graduation in 2004 and post graduation in 2006 from the University of Allahabad. Ms Mehta is a recipient of University Gold Medal for topping in B.Sc. and M. Sc. Ms Mehta has qualified NET for JRF in 2006 and joined the research group of Dr. Watal for D.Phil. in 2007. Presently Ms Mehta is working as SRF in the Department of Chemistry, University of Allahabad. Her uncanny aptitude and insatiable zest for research has resulted in authoring various National and International publications of high repute. Ms Mehta has presented her work in many conferences of National and International level and was invited to Switzerland, Basel, in 3rd International ATTD Conference on Advanced Technologies \& Treatments for Diabetes, where she presented her work in Feb 2010. Broad area of her research interest is Medicinal Chemistry including development of phytomedicines for treatment of diabetes and complications related to it. Currently, Ms Mehta is involved in developing to-morrows medicine to-day.

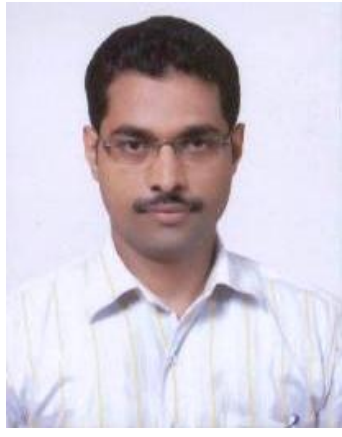

Nilesh Kumar Rai has qualified NET in 2005 and joined the research group of Prof A. K. Rai of the Department of Physics, University of Allahabad. Dr. Nilesh had worked as Senior Research Fellow in a SASE-DRDO sponsored project entitled, "Detection and Quantification of Contaminants (trace and major elements) in Ice and Snow", and has successfully completed it. Dr. Nilesh has published more than eleven research papers in journals of high repute and one book chapter in Methods in Molecular Biology: Advanced Protocols in Oxidative Stress. Major research interests of Dr. Nilesh are Study of different materials using laser spectroscopic techniques. During his D.Phil. work Dr. Nilesh has developed laser based analytical technique named as LIBS (Laser-induced Breakdown Spectroscopy) for study of different types of materials of Environmental, Herbal and Biological interest. Dr. Nilesh had visited Berlin, Germany in 2008 to attend and present his work in a conference, LIBS 2008. Dr. Nilesh has obtained his D.Phil. in Science in Nov. 2009 and then joined as a Research Associate, CSIR. At present he has availed D.S. Kothari fellowship of UGC and joined Department of Inorganic \& Physical Chemistry, Indian Institute of Science (I.I.Sc.), Banglore, India.

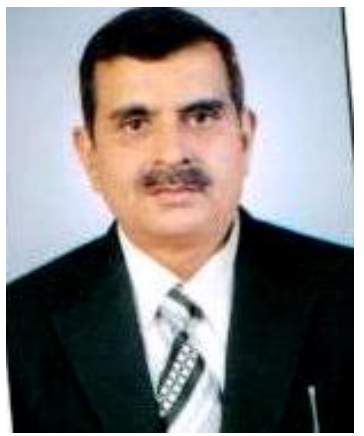

Born in 1958 in village Reotipur, Dist. Ghazipur, UP, India, A.K. Rai obtained his M. Sc. and PhD from the Banaras Hindu University (BHU), in 1978 and 1983 respectively. He was Max- Planck Post Doctoral Fellow at Max-Planck Institute, Munich, Germany, in 198485. During 1985-88, he has worked as Pool Scientist at the Physics Department, BHU, Varanasi. He has been awarded ISCA, Young Scientist Award in 1987, based on his work on laser Optogalvanic Spectroscopy. He joined G.B. Pant University of Agriculture \& Technology as Assistant Professor in 1988 and became Associate professor in 1998 and has developed the experimental facility of Photoacoustic Spectroscopy. He has visited ICTP, Trieste, Italy, in 1987 and 1992. He has worked as Visiting Professor at Mississippi State University, USA, from 2000-02 and has developed a laser-induced breakdown spectroscopy sensor for the online analysis of molten Aluminum alloy. In 2004 Dr. has joined University of Allahabad as a Professor of physics and has developed the experimental research facility in the area of laser-induced breakdown spectroscopy for the study of materials. Prof Rai has been elected as Recorder of the Physical Science Section for 2010-2011 \& 2011-2012 (98th and 99th Sessions) of the Indian Science Congress Association and as Member of the National
Academy of Sciences, India (M.N.A.Sc.). He is the life member of Life member of: Laser and Spectroscopy Society of India, Indian Laser Association, Indian Science Congress Association and High Energy Materials Society of India. He has published over 90 research papers in national and international journals and has presented research papers and given invited talk in many (over 35) conferences of national and international repute. He has worked as Principal Investigator in several projects funded by DRDO/DST/CSIR. He has guided six Ph. D. students.

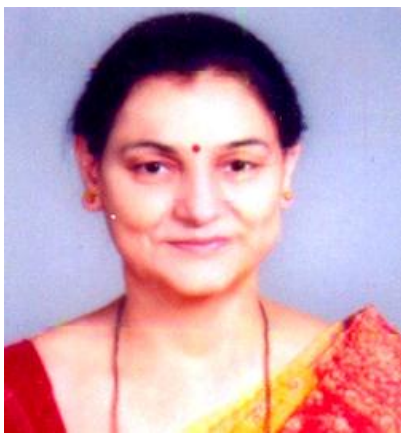

Geeta Watal, a graduate from BHU, did her post graduation in Chemistry from the University of Allahabad in 1979. A University Gold Medalist with a First Rank in M.Sc, Dr. Watal, obtained her D. Phil. in 1983 and availed different fellowships viz. JRF, SRF and PDF from 1980-84. She worked as a Pool Scientist during 1985-88, and then as a Research Associate from 1990-94. Dr. Watal joined as a Lecturer in 1994 and is now serving as a Associate Professor in the same department. Dr. Watal is actively engaged in Medicinal Research specifically in treating Diabetes and its complications. Nine of her research students have been awarded D. Phil. and many more are still working under her able guidance. She had been invited by the American Diabetes Technology Society to Philadelphia, Pennsylvania, USA in Oct.2004, where she presented her work. She had also been to Corvallis, Oregon, USA in July 2005 and to Arlington, Virginia, USA in Aug, 2006 for presenting her work in annual meets of American Society of Pharmacognosy. She has handled a number of projects as PI as well as Co-PI funded by UGC, ICMR and NMPB. Dr. Watal is a member of American Chemical Society and American Society of Pharmacognosy and life member of Indian Science Congress and Bio-informatics Institute of India. In connection with her collaborative research work, she has travelled to New Paltz campus, New York University, USA in Oct, 2007 and Harward University, Washington, USA in Oct, 2008. Her National collaborators are from All India Institute of Medical Sciences, New Delhi and Delhi University. Dr. Watal has five Patents for her inventions and more than eighty publications in journals of high repute to her credit. Recently she has published two book chapters on Advanced Protocols in Oxidative Stress in an edited book of International publisher, "Methods in Molecular Biology Series". Dr. Watal is currently involved in a screening program of herbal extracts from India, China and Nigeria, for their bioactivities. She has designed the laboratory control and test procedures, to assure the potency and purity of activity testing, which can be ratified from any independent lab in the world. She has invented highly effective oral medication for diabetic patients. She believes that natural resources can play a big role in Diabetes management. Her motto is "Integration of natural medicine into conventional treatments".

\section{Introduction}

Trichosanthes dioica, (green potato) is cultivated widely in eastern India. It is a rich source of carbohydrates, vitamin $\mathrm{A}$, and vitamin $\mathrm{C}$ and major nutrients and certain essential trace elements such as magnesium, potassium, copper, sulfur, and chlorine which that seems an important role in human physiology [1-4]. The phytochemical investigation carried out in past with other species of Trichosanthes reports a number of different classes of compounds viz. flavonoids [5], alkaloids, glycosides [6], terpenes and sterols [7], from fruits and seeds of the plant could be responsible for their medicinal value.

Flavonoids are secondary metabolites [8] helps in regulation of normal plant development [9] and are responsible for colors of plant organs. These compounds are not only present in plants as constitutive agents but are also accumulated in plant tissues in response to microbial attack [10]. Flavonoids form a large group of natural 
phenolic compounds, considered as safe and natural antioxidant [11].

Traditional use of Trichosanthes dioica in folk medicines for treating diabetes mellitus [1] and presence of flavonoids [5] in addition to trace elements viz. $\mathrm{Cu}, \mathrm{K}$ and $\mathrm{Mg}$ etc. [1] inspired us for conducting this study. It has been reported that the presence of flavonoids and trace elements viz. $\mathrm{Cu}, \mathrm{K}$ and $\mathrm{Mg}$ are responsible for antidiabetic activity of plants [4]. Laser-induced breakdown spectroscopy (LIBS) is a useful technique for varied applications. The most important is material analysis. The interaction of a high power- pulsed laser beam with the surface of the target material leads to the formation of a laser- induced plasma. Optical emission from the plasma consists of atomic and ionic spectral lines, characteristic of the constituent species, superimposed on a broad band continuum that is due to electron-ion recombination and free-free interactions. Identification of spectral lines and measurement of their intensities provides qualitative and quantitative information about the constituents of the target material $[12,13]$. In the present study the LIBS has been used for identifying the complete phytoelemental profile of Trichosanthes dioica responsible for its bioactivity. Based on natural product technology one known and two unknown flavonoids have also been isolated from the seeds of Trichosanthes dioica in this study.

\section{Experimental}

\section{Preparation of material}

Fresh ripe fruits of Trichosanthes dioica were purchased from the local market of Allahabad, India and authenticated by Prof. Satya Narayan, Taxonomist, Department of Botany, University of Allahabad, India. A voucher specimen (AA/512/06) has been submitted. The fruits were cut into pieces and the seeds were collected and shade dried. The dried seeds $(2 \mathrm{~kg})$ were mechanically crushed and extracted with distilled water using Soxhlet up to $48 \mathrm{~h}$. The extract was filtered and concentrated in rotatory evaporator at $35 \pm 5{ }^{\circ} \mathrm{C}$ under reduced pressure, to obtain semisolid material, which was then lyophilized to get a powder (yield about $10.5 \% \mathrm{w} / \mathrm{w}$ ).

\section{Chemicals}

Silica gel, conventional solvents viz. hexane, benzene, ethyl acetate, dichloromethane, choloroform, ethanol, methanol and solvents viz. acetyl chloride, acetic anhydride, glacial acetic acid, conc. $\mathrm{H}_{2} \mathrm{SO}_{4}$ and $\mathrm{ZnCl}_{2}$ etc were purchased from Merck India Limited.

\section{Extraction and isolation of compounds}

The whole seed was mechanically crushed and extracted with different solvents in order of increasing polarity viz. hexane, benzene, ethyl acetate and ethanol. The ethanol fraction was loaded in a silica gel column and was run in gradient of increasing polarity using different solvents (hexane $\rightarrow$ ethyl acetate $\rightarrow$ chloroform $\rightarrow$ ethanol $\rightarrow$ methanol $\rightarrow 30 \%$ of aqueous methanol). Three pure compounds 1-3 were isolated from the last fraction of $30 \%$ aqueous methanol and characterized. TLC reveals the Rf of compounds 1, 2 and 3 as $0.45,0.52$ and 0.65 respectively (DCM: Methanol, 3:7).

\section{Characterization of compounds}

Melting points were determined by open glass capillary tubes and are uncorrected. IR and UV spectra were recorded on Perkin-Elmer 599 B and Shimadzu UV-250 spectrometers respectively. ${ }^{1} \mathrm{H}$ NMR, ${ }^{13} \mathrm{C}$ NMR, spectra were recorded in DMSO- $d_{6}$ on Bruker 300 DPX, FT NMR $\left({ }^{1} \mathrm{H}: 400 \mathrm{MHz},{ }^{13} \mathrm{C}: 100 \mathrm{MHz}\right)$ spectrometers. Mass spectra were measured on a JEOL AX 500 spectrometer. Silica gel G (60-120 mesh) was used for TLC and column chromatography, respectively. The collected fractions of the column were subjected to check homogeneity. Chromatographically identical fractions were combined and concentrated. The TLC spots were visualized under UV light and $I_{2}$ exposure as well. Spectral data for compound 1 and 2 was as follows:

Compound 1:

$\mathrm{UV}\left(\mathrm{CH}_{3} \mathrm{OH}\right): \lambda_{\max } \quad 371$ and $259 \mathrm{~nm}$.

IR $(\mathrm{KBr}) v_{\max } .3442,3050,1702,1605,1585$ and 1455 $\mathrm{cm}^{-1}$.

${ }^{1} \mathrm{H}$ NMR (400 MHz) 7.21 (1 H, s, H-6'), 7.02 (1 H, s, H3), $6.61\left(1 \mathrm{H}, \mathrm{d}, J_{6,8}=\left(\mathrm{DMSO}-d_{6}+\mathrm{D}_{2} \mathrm{O} / \mathrm{TMS}\right) 2.1 \mathrm{~Hz}, \mathrm{H}-\right.$ $\delta 8), 6.53\left(1 \mathrm{H}, \mathrm{s}, \mathrm{H}-3^{\prime}\right), 6.49\left(1 \mathrm{H}, \mathrm{d}, J_{6,8}=2.1 \mathrm{~Hz}, \mathrm{H}-6\right)$, $3.91(3 \mathrm{H}, \mathrm{s}, \mathrm{OMe})$ and $3.97(3 \mathrm{H}, \mathrm{s}, \mathrm{OMe})$.

${ }^{13} \mathrm{C}$ NMR (100 MHz) $185.8(>\mathrm{C}=\mathrm{O}), 169.2(\mathrm{C}-7), 163.9$ (C-2), 163.1 (C-5), (DMSO- $\left.d_{6}+\mathrm{D}_{2} \mathrm{O} / \mathrm{TMS}\right) 160.5$ (C-9), $152.5\left(\mathrm{C}-5^{\prime}\right), 150.9$ (C-2'), $147.3\left(\mathrm{C}-4^{\prime}\right)$,

120.3 (C- 6'), 118.2 (C-1'), 116.5 (C-3'), 105.8 (C-3), 105.1 (C-10), 98.5 (C-6), 96.7 (C-8), 57.1 and $56.8(2 \times$ $\mathrm{OMe})$.

EIMS (m/z) $330\left(\mathrm{M}^{+}\right)$; observed 330.074

Compound 2:

$\mathrm{UV}\left(\mathrm{CH}_{3} \mathrm{OH}\right): \lambda_{\max } \quad 366$ and $258 \mathrm{~nm}$.

${ }_{1} \mathrm{IR}(\mathrm{KBr}) v_{\max } 3445,3046,1705,1599,1579$ and $1459 \mathrm{~cm}-$

${ }^{1} \mathrm{H}$ NMR (400 MHz) $\delta 7.10\left(1 \mathrm{H}, \mathrm{d}, J_{4^{\prime}, 6^{\prime}}=2.5 \mathrm{~Hz}, \mathrm{H}-6^{\prime}\right)$, 7.03 (1 H, s, H-3), (DMSO-d $\left.d_{6}+\mathrm{D}_{2} \mathrm{O} / \mathrm{TMS}\right) 6.89$ (1 H, d, $\left.J_{4^{\prime}, 6^{\prime}}=2.5 \mathrm{~Hz}, \mathrm{H}-4^{\prime}\right), 6.67\left(1 \mathrm{H}, \mathrm{d}, J_{6,8}=2.1 \mathrm{~Hz}, \mathrm{H}-8\right), 6.61$ $\left(1 \mathrm{H}, \mathrm{s}, \mathrm{H}-3^{\prime}\right), 6.48\left(1 \mathrm{H}, \mathrm{d}, J_{6,8}=2.1 \mathrm{~Hz}, \mathrm{H}-6\right)$ and 3.87 (3 $\mathrm{H}, \mathrm{s}, \mathrm{OMe})$.

${ }^{13} \mathrm{C}$ NMR (100 MHz) $185.8(>\mathrm{C}=\mathrm{O}), 184.9(>\mathrm{C}=\mathrm{O}), 168.8$ (C-7), 163.8 (C-2), (DMSO-d $\left.d_{6}+\mathrm{D}_{2} \mathrm{O} / \mathrm{TMS}\right) 162.8(\mathrm{C}-5)$, 159.6 (C-9), 151.3 (C-2'), 152.6 (C-5'), 121.7 (C-6'), $120.9\left(\mathrm{C}-1^{\prime}\right), 116.5\left(\mathrm{C}-3^{\prime}\right), 115.2$ (C-4'), 105.9 (C-3), 105.1 (C-10), 99.1 (C-6), 96.2 (C-8) and 57.5 (OMe).

EIMS (m/z) $300\left(\mathrm{M}^{+}\right)$; observed 330.063 


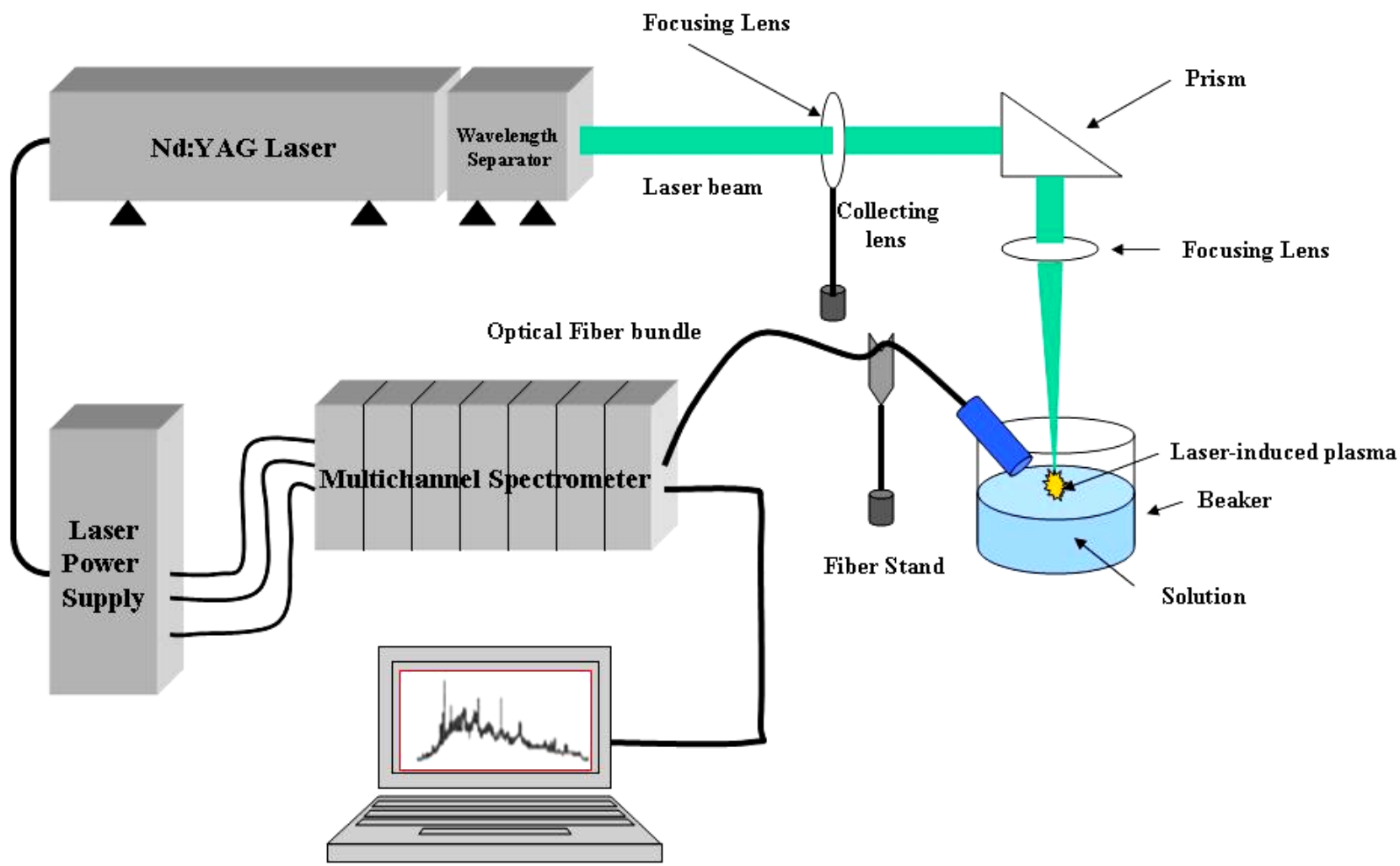

Computer

Fig. 1. LIBS experimental setup.

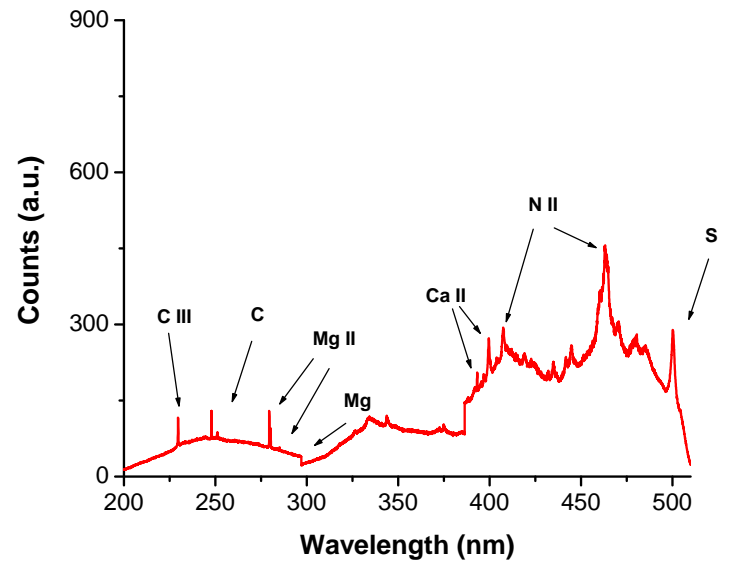

Fig. 2. LIBS spectra of Trichosanthes dioica seeds in spectral range 200-500 nm.

\section{Detection of trace elements through LIBS}

A schematic diagram of the experimental setup for recording the LIBS spectra is shown in Fig. 1. The LIB spectra of $T$. dioica seeds extract powder, dissolved in distilled water, was recorded for identifying the presence of best set of elements responsible for its antidiabetic efficacy. The solution was prepared by dissolving $1.0 \mathrm{~g}$ of lyophilized material in $10 \mathrm{ml}$ of distilled water. The spectra presented in Fig. 2 and 3, are the average of 100 scans (100 shots). The 4-channel spectrometer equipped with Change Coupled Device (CCD) (Ocean optics LIBS 2000+) comprising the 4-grating was used to get the dispersed light from the plasma. The initial three gratings had the resolution of $0.1 \mathrm{~nm}$ covering the wavelength range from 200-310 nm, 310-400 nm and 400-510 nm, respectively, while the fourth grating, termed a broad band grating, covered the wavelength range from $200-1100 \mathrm{~nm}$ and had a resolution of $0.75 \mathrm{~nm}$. All four gratings were used simultaneously to record the LIBS spectra. A pulsed laser beam from a Q- switched Nd: YAG laser (Continuum Surellite III-10) was focused on the sample using a converging lens Quartz) of $30 \mathrm{~cm}$ focal length, the temperature of the locally heated region rose rapidly and resulted in plasma formation on sample surface. The emitted light from micro-plasma was collected using an optical fiber tip placed in the vertical plane at $45^{\circ}$ with respect to the laser beam and finally fed into an entrance slit of the multichannel spectrometer (Ocean Optics 
LIBS2000+) equipped with CCD and 4 gratings. In case of aqueous extract of $T$. dioica the LIBS spectra were recorded at a repetition rate of $2 \mathrm{~Hz}$ and 175 -mJ-laser energy.

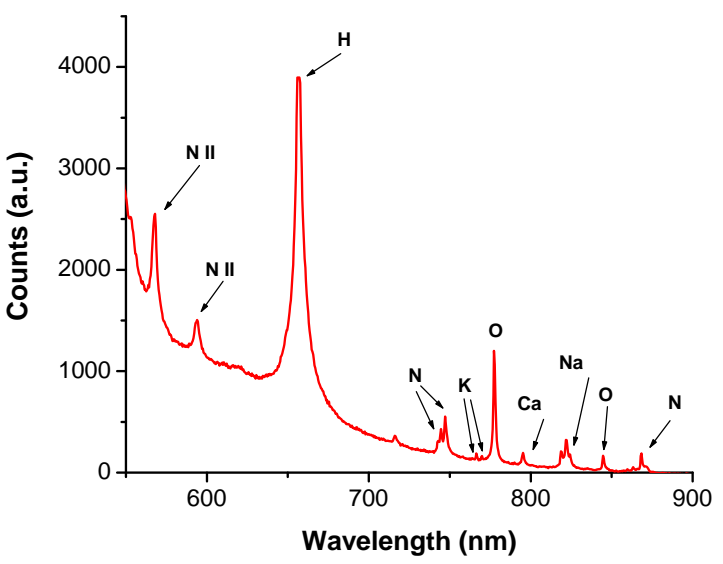

Fig. 3. LIBS spectra of Trichosanthes dioica seeds in spectral range 500$900 \mathrm{~nm}$.

\section{Results and discussion}

\section{Preliminary phytochemical investigation}

Initial phytochemical analysis of the seeds extract powder was carried out and flavonoids were identified according to Kokte and Harborne $[\mathbf{1 4}, \mathbf{1 5}]$. The plant extract powder $(200 \mathrm{mg}$ ) was dissolved in $100 \mathrm{ml}$ ethanol and filtered. $2 \mathrm{ml}$ of this filtrate was mixed with equal volume of concentrated HCL followed by addition of the Magnesium ribbon. The appearance of tomato red color indicated the presence of flavonoids in the extract of Trichosanthes dioica seeds. The similar test was performed for each solvent fraction and ethanol fraction was found to be positive.

\section{Isolation of compound}

Ethanol fraction of Trichosanthes dioica seeds gave three pure compounds, out of which two were unknown (compound 1 and compound 2) and one was known (compound 3). Molecular formulas of both the unknown compounds were established by their elemental and spectral analysis viz. UV, IR, ${ }^{1} \mathrm{H}$ and ${ }^{13} \mathrm{C}$ NMR as follows:

\section{Compound 1 (Structure 1):}

Molecular formula: $\mathrm{C}_{17} \mathrm{H}_{14} \mathrm{O}_{7}$; Color and mp. Pale yellow powder; m.p. $58-59{ }^{\circ} \mathrm{C}$; Elemental analysis: found $\mathrm{C}$ $=61.57 \%, \mathrm{H}=4.51 \%, \mathrm{O}=34.22 \%$; Cal. $\mathrm{C}=61.82 \%, \mathrm{H}=$ $4.27 \%, \mathrm{O}=33.91 \%$. UV absorption maxima of compound $1 \mathrm{in} \mathrm{CH}_{3} \mathrm{OH}$ appeared at 371 and $259 \mathrm{~nm}$. The IR spectrum of compound 1 showed absorptions at 3442, 3050, 1702, 1605,1585 and $1455 \mathrm{~cm}^{-1}$ indicating thereby, the presence of hydroxyl, carbonyl and aromatic moieties in the molecule. The ${ }^{1} \mathrm{H}$ NMR spectrum indicated the presence of five $\mathrm{sp}^{2}$-methine protons at $\delta 7.21(1 \mathrm{H}, \mathrm{s}), 7.02(1 \mathrm{H}, \mathrm{s})$, $6.61(1 \mathrm{H}, \mathrm{d}, J=2.1 \mathrm{~Hz}), 6.53(1 \mathrm{H}, \mathrm{s})$, and $6.49(1 \mathrm{H}, \mathrm{d}, J$ $=2.1 \mathrm{~Hz})$, and two methoxy protons at $\delta 3.91(3 \mathrm{H}, \mathrm{s})$ and $3.97(3 \mathrm{H}, \mathrm{s})$. The ${ }^{13} \mathrm{C}$ NMR showed seventeen carbon signals at $\delta 185.8,169.2,163.9,163.1,160.5,152.5,150.9$,
$147.3,120.3,118.2,116.5,105.8,105.1,98.5,96.7,57.1$ and 56.8. The ${ }^{1} \mathrm{H}$ NMR signals at $\delta 6.61$ and 6.49 (each 1 $\mathrm{H}, \mathrm{d}, J=2.1 \mathrm{~Hz}$ ) were assigned as protons at C-8 and C-6 positions while signals at $\delta 6.53$ and 7.21 (each $1 \mathrm{H}$, s) were assigned as protons at $\mathrm{C}-3^{\prime}$ and $\mathrm{C}^{\prime} 6^{\prime}$ positions respectively. Furthermore, these spectral data are in agreement with the earlier reports of literature ${ }^{5,16,17}$. Thus, on the basis of the above spectral studies, the compound 1 was assigned as $2^{\prime}, 4^{\prime} 5$,-trihydroxy-5',7-dimethoxyflavone and its systematic name is 5-hydroxy-2-(2,4-dihydroxy-5methoxyphenyl)-7-methoxy-4H-chromen-4-one.

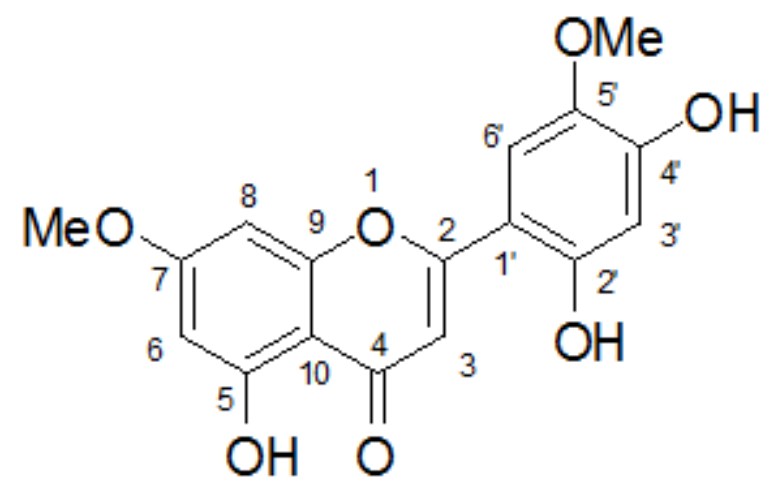

Structure 1. Chemical structure of compound 1: 5-Hydroxy-2-(2,4dihydroxy-5-methoxyphenyl)-7-methoxy-4H-chromen-4-one.

\section{Compound 2 (Structure 2):}

Molecular formula: $\mathrm{C}_{16} \mathrm{H}_{12} \mathrm{O}_{6}$; Color and mp.: Pale yellow powder; m.p. $118-120{ }^{\circ} \mathrm{C}$; Elemental analysis: Found $\mathrm{C}=$ $64.37 \%, \mathrm{H}=3.85 \%, \mathrm{O}=32.08 \%$; Cal. $\mathrm{C}=64.00 \%, \mathrm{H}=$ $4.03 \%, \mathrm{O}=31.97 \%$.

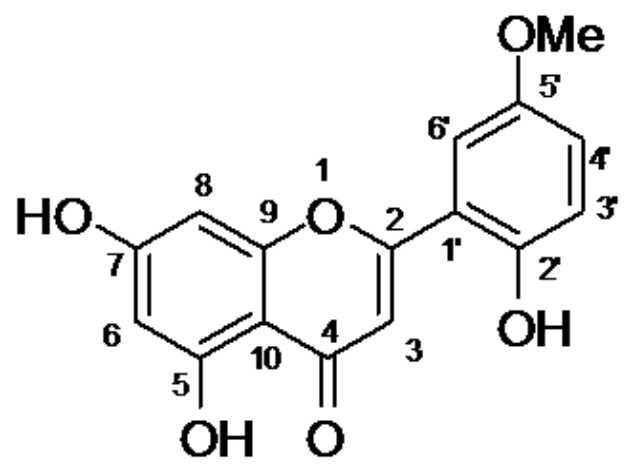

Structure 2. Chemical structure of compound 2: 5,7-dihydroxy-2-(2hydroxy-5-methoxyphenyl)-4H-chromen-4-one.

UV absorption maxima of compound 2 in $\mathrm{CH}_{3} \mathrm{OH}$ appeared at 366 and $258 \mathrm{~nm}$. The IR spectrum of compound 2 showed absorptions at 3445, 3046, 1705, 1599,1579 and $1459 \mathrm{~cm}^{-1}$ indicating thereby, the presence of hydroxyl, carbonyl and aromatic moieties in the molecule. The ${ }^{1} \mathrm{H}$ NMR spectrum indicated the presence of six sp ${ }^{2}$-methine protons at $\delta 7.10(1 \mathrm{H}, \mathrm{d}, J=2.5 \mathrm{~Hz}), 7.03$ $(1 \mathrm{H}, \mathrm{s}), 6.89(1 \mathrm{H}, \mathrm{d}, J=2.5 \mathrm{~Hz}), 6.67(1 \mathrm{H}, \mathrm{d}, J=2.1$ $\mathrm{Hz}), 6.61(1 \mathrm{H}, \mathrm{s})$, and $6.48(1 \mathrm{H}, \mathrm{d}, J=2.1 \mathrm{~Hz})$, and one methoxy proton at $\delta 3.87(3 \mathrm{H}, \mathrm{s})$. The ${ }^{13} \mathrm{C}$ NMR showed 
sixteen carbon signals at $\delta 184.9,168.8,163.8,162.8$, $159.6,151.3,152.6,121.7,120.9,116.5,115.2,105.9$, 105.1, 99.1, 96.2 and 57.5. The ${ }^{1} \mathrm{H}$ NMR signals at $\delta 6.67$ and 6.48 (each $1 \mathrm{H}, \mathrm{d}, J=2.1 \mathrm{~Hz}$ ) were assigned as protons at C-8 and C-6 positions. Similarly, ${ }^{1} \mathrm{H}$ NMR signals at $\delta$ 7.10 and 6.89 (each $1 \mathrm{H}, \mathrm{d}, J=2.5 \mathrm{~Hz}$ ) were assigned as protons at C-6' and C-4' positions while signals at $\delta 7.03$ and 6.61 (each $1 \mathrm{H}, \mathrm{s}$ ) were assigned as protons at $\mathrm{C}-3$ and C-3' positions respectively. Furthermore, these spectral data are in agreement with the earlier reports of literature $[5,16,17]$. Thus, on the basis of detailed spectral studies the compound $\mathbf{2}$ was assigned as 2',5,7-trihydroxy-5'methoxyflavone and its systematic name is 5,7-dihydroxy2-(2-hydroxy-5-methoxyphenyl)-4H-chromen-4-one and its all characterization data has given.

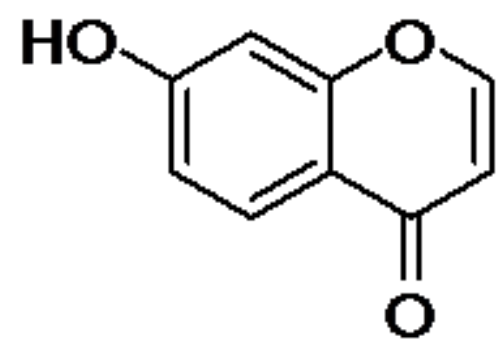

Structure 3. Chemical structure of compound 3: 7-Hydroxy- $4 \mathrm{H}-$ chromen-4-one.

Compound $\mathbf{3}$ is a known compound and was authenticated as 7-Hydroxy-4H-chromen-4-one by comparing its data with the reported ones in the literature [18]. Though, its isolation from Phlojodicarpus villosus [19] and recently from Trichosanthes kirilowi [5], has been reported but this is the first report of isolation of this compound from Trichosanthes dioica.

\section{LIBS analysis of Trichosanthes dioica extract}

LIBS spectra of $T$. dioica seeds extract, shown in Fig. 2 and $\mathbf{3}$, were taken at optimized experimental conditions. It clearly revealed the presence of $\mathrm{Mg}, \mathrm{Fe}, \mathrm{Na}, \mathrm{K}, \mathrm{Zn}, \mathrm{Ca}, \mathrm{H}$, $\mathrm{O}, \mathrm{C}$ and $\mathrm{N}$ elements in the spectral range from $200 \mathrm{~nm}$ to $900 \mathrm{~nm}$. According to the Boltzmann's distribution law, intensity is directly related to concentration [20].

Therefore, the intensity of the observed spectral lines corresponding to major and minor elements present in the extract is not only an indication of their concentration but it also assists in defining their role in diabetes as well as in diabetes-induced oxidative stress management. The ratio of intensities of the detected elements $(\mathrm{Mg}, \mathrm{Fe}, \mathrm{Na}, \mathrm{K}, \mathrm{Ca}, \mathrm{C}$, $\mathrm{H}, \mathrm{O}$ and $\mathrm{N}$ ) to the intensities of reference lines ( $\mathrm{C}$ and $\mathrm{O}$ that are the essential elements of plant materials), was estimated to evaluate their proportional concentration. Since gratings with different resolutions were used, the whole spectra was divided in two sections: the first (resolution $0.1 \mathrm{~nm}$ ) covered the wavelength range from $200-510 \mathrm{~nm}$ and the second $(0.75 \mathrm{~nm}$ resolution) spanning the wavelength range between 510 and $1100 \mathrm{~nm}$. To find the intensity ratios of spectral lines, the $C$ line at $247.88 \mathrm{~nm}$ (as a reference line for the spectral range of $\lambda 200-510 \mathrm{~nm}$ ) and the $\mathrm{O}$ line at $844.10 \mathrm{~nm}$ (as the reference line for spectral wavelength range of 500-1100) $\mathrm{nm}$ have been selected. Calculated intensity ratios of $\mathrm{Fe} / \mathrm{C}, \mathrm{Mg} / \mathrm{C}, \mathrm{Ca} / \mathrm{C}$, $\mathrm{K} / \mathrm{O}, \mathrm{Na} / \mathrm{O}, \mathrm{H} / \mathrm{O}$ and $\mathrm{N} / \mathrm{O}$ are given in Table $\mathbf{1}$ and $\mathbf{2}$.

Demand of interdisciplinary research is increasing in the new millennium. The present study is an excellent example of unique combination of Physics, Chemistry and Biological techniques used for unveiling the scientific facts. LIBS can scientifically unfold the mystery enclosed in medicinal plants based on their inorganic constituents. The study is based on systematic, scientific and critical evaluation of Indian medicinal herbs in treating diabetes mellitus. Since, there are no reports till date on glycemic elemental assessment of such herbs based on LIBS, therefore, the present study is the first reporting of its type. It deals with the monitoring of the role of the trace mineral elements, present in seeds extracts in management of diabetes and its complications.

Table 1. Intensity ratio of elements with C (247.856 nm).

\begin{tabular}{cccc}
\hline Element & Wavelength $(\mathbf{n m})$ & Element/Ref & Intensity Ratio \\
\hline $\mathbf{M g}$ & 279.532 & $\mathrm{Mg} / \mathrm{C} 247.856)$ & $\mathbf{1 . 1 0 5 1 8}$ \\
$\mathbf{M g}$ & 280.255 & $\mathrm{Mg} / \mathrm{C}(247.856)$ & $\mathbf{0 . 6 0 5 6 9}$ \\
$\mathbf{C}$ & 247.856 & $\mathrm{C} / \mathrm{C}(247.856)$ & $\mathbf{1}$ \\
$\mathbf{C}$ & 229.673 & $\mathrm{C} / \mathrm{C}(247.856)$ & $\mathbf{1 . 2 2 1 0 4}$ \\
$\mathbf{C a}$ & 393.347 & $\mathrm{Ca} / \mathrm{C}(247.856)$ & $\mathbf{0 . 5 9 1 9 7}$ \\
$\mathbf{C a}$ & 396.867 & $\mathrm{Ca} / \mathrm{C}(247.856)$ & $\mathbf{0 . 3 4 1 9 7}$ \\
$\mathbf{N}$ & $\mathbf{3 9 9 . 4 7 7}$ & $\mathbf{N} / \mathbf{C}(\mathbf{2 4 7 . 8 5 6})$ & $\mathbf{2 . 6 9 4 6 1}$ \\
\hline
\end{tabular}

Table 2. Intensity ratio of elements with O (399.477 nm).

\begin{tabular}{cccc}
\hline Element & Wavelength $(\mathbf{n m})$ & Element/Ref & Intensity Ratio \\
\hline $\mathbf{N}$ & 567.956 & $\mathrm{~N} / \mathrm{O}(399.477)$ & $\mathbf{1 . 4 0 6 7 2}$ \\
$\mathbf{N}$ & 594.165 & $\mathrm{~N} / \mathrm{O}(399.477)$ & $\mathbf{0 . 4 9 1 9 7}$ \\
$\mathbf{N}$ & 744.12 & $\mathrm{~N} / \mathrm{O}(399.477)$ & $\mathbf{0 . 1 0 1 1 1}$ \\
$\mathbf{N}$ & 746.75 & $\mathrm{~N} / \mathrm{O}(399.477)$ & $\mathbf{0 . 3 3 4 8 1}$ \\
$\mathbf{N}$ & 868.395 & $\mathrm{~N} / \mathrm{O}(399.477)$ & $\mathbf{0 . 1 0 3 2 9}$ \\
$\mathbf{H}$ & 656.331 & $\mathrm{H} / \mathrm{O}(399.477)$ & $\mathbf{1 3 . 0 3 1 6 3}$ \\
$\mathbf{O}$ & 777.194 & $\mathrm{O} / \mathrm{O}(399.477)$ & $\mathbf{1}$ \\
$\mathbf{K}$ & 766.445 & $\mathrm{~K} / \mathrm{O}(399.477)$ & $\mathbf{0 . 0 2 4 7 1}$ \\
$\mathbf{K}$ & 769.94 & $\mathrm{~K} / \mathrm{O}(399.477)$ & $\mathbf{0 . 0 1 9 1 5}$ \\
$\mathbf{N a}$ & $\mathbf{8 1 8 . 2 6}$ & $\mathrm{Na} / \mathbf{O}(\mathbf{3 9 9 . 4 7 7})$ & $\mathbf{0 . 0 5 8 0 7}$ \\
\hline
\end{tabular}

Our results and discussion clearly show that the specific concentration of these elements play an important role in diabetes management. Function of most of these elements has already been reported in different literature. Most essential trace mineral elements act preliminary as catalyst or as co-factors in enzyme systems [21]. The role of some inorganic elements like $\mathrm{Ca}, \mathrm{K}, \mathrm{Mg}, \mathrm{Al}$, and traces of Fe etc. in the improvement of impaired glucose tolerance and their indirect role in the management of diabetes mellitus are being increasingly recognized. $\mathrm{Ca}$ and other trace elements play an important role in the release of insulin from $\beta$ cells of islets of Langerhans by activating gene expression via CREP (calcium responsive element binding protein), which is responsible for exocytosis of stored insulin [22]. According to recent reports, specific concentration of $\mathrm{K}$ takes part in carbohydrate metabolism; it is active in glycogen and glucose metabolism, converting glucose to glycogen that can be stored in the liver for energy [23]. Mg helps in maintaining this specific amount of $\mathrm{K}$ in the cell thus, $\mathrm{Na}$ and $\mathrm{K}$ balance is finely tuned. $\mathrm{Mg}$ is a cofactor in various enzyme pathways involved in glucose oxidation and it also modulates glucose transport 
across cell membrane. Hypomagnesaemia is common in patients with diabetes due to the excess of urinary $\mathrm{Mg}$ losses. Deficiency of $\mathrm{Mg}$ can potentially cause state of insulin resistance. Hence, low levels of $\mathrm{Mg}$ are commonly seen in the people with diabetes [24]. There is evidence that $\mathrm{Mg}$ supplementation may be helpful in improving insulin resistance [4]. Since, its role in glycemic control was unknown therefore the present study is a forwarding step in this direction.

\section{Conclusion}

In the present study, we were inferring isolated flavonoids and trace elements which can be very well correlated with medicinal value of $T$. dioica. Also, the results clearly demonstrate that LIBS technique can be used as a basic yet powerful tool for determining the presence of glycemic elements.

\section{Acknowledgements}

The authors are grateful to BRNS and ICMR, New Delhi, India, for providing the financial assistance. PKR is thankful to ICMR for the award of R.A.

\section{References}

1. Sharma, G.; Sarkar, A.; Pachori, S.B.; Pant, M.C. Indian drug 1989, 27, 24.

2. Rai, P.K.; Jaiswal, D.; Diwakar, S.; Watal G. Pharmaceutical Biology 2008, 46, 360.

3. Rai, P.K.; Jaiswal, D.; Singh, R.K.; Gupta, R,; Watal, G. Pharmaceutical Biology 2008, 46, 894.

4. Kar, A.; Choudhary, B.K.; Bandyopadhyay, N.G. Journal of Ethnopharmacology 1999, 64, 179.

5. Rahman, M.A.A.; Moon, S.S. Bulletin of Korean Chemical Society 2007, 28, 1261.

6. Kanchanapoom, T.; Ryoji, K.; Yamasaki, K. Phytochemistry 2002, 59, 215.

7. Akihisa, T.; Kimura, Y.; Kasahara, Y.; Kumaki, K..; Thakur, S.; Tamura, T. Phytochemistry, 1997, 46, 1261.

8. Harborne, J.B.; Williams, C.A. Phytochemistry 2000, 55,481 .

9. Lazar, G.; Goodman, H.M. Proceedings of the National Academy of Science USA 2006, 103, 472.

10. Harborne, J. B. Biochemical Systematics and Ecology 1999, 27, 335 .

11. Wang, H.; Nair, M.G.; Strasburg, G.M.; Booren, A.M.; Gray, J.I. Journal of Natural Product, 1999, 62, 86.

12. Rai, P. K,; Rai, N.K,; Rai, A.K,; Watal, G. Instrumentation Science and Technology 2007, 35, 507.

13. Rai, P.K.; Jaiswal, D.; Rai, N.K.; Pandhija, S.; Rai, A.K,; Watal, G. Lasers in Medical Sciences 2009, 24, 761.

14. Kokte, C.K. Expert Opinion on Biological Therapy 1994, 3, 127.

15. Harborne, J.B. Methods of extraction and isolation. London, Chapman and Hall, 1998, pp 60-66.

16. Kuwabara, H.; Mouri, K.; Otsuka, H.; Kasai, R.; Yamasaki, K. Journal of Natural Product 2003, 66, 1273.
17. Stochmal, A.; Simonet, A.M.; Macias, F.A.; Oleszek, W. Journal of Agriculture Food Chemistry 2001, 49, 5310.

18. Yu, D.; Chen, C.H.; Brossi, A.; Lee, K.H. Journal of Medicinal Chemistry 2004, 47, 4072.

19. Gantimur, D.; Semenov, A. A.. Chemistry of Natural Comounds (Engl. Transl.) 1984, 20, 362.

20. Sabsabi, M.; Cielo, P. Applied Spectroscopy 1995, 49, 499.

21. Underwood, E.J.; Mertz, W. Trace elements in human and animal nutrition. Academic Press, New York, 1987, 2, pp. 11-17.

22. Giugliano, M.; Bove, M.; Grattaro, M. IEEE Transact Biomed Engineer 2000, 47, 611.

23. Yeh, G.L.; Eisenberg, D.M.; Kaptchuk, T.J.; Phillips, R.S. Diabetes care, 2003, 26, 1277.

24. Ridaura, R.L.; Willett, W.C.; Rimm, E.B.; Liu, S.M.; Stampeer, J.; Manson, J.E.; Hu, F.B. Diabetes care 2004, 27, 134. 